\title{
Prevalence of Human Papillomavirus Infection in Women Attending a Sexually Transmitted Disease Clinic
}

\author{
Takeyoshi KUBOTA ${ }^{1}$, Kazuhisa ISHI', Masaaki SUZUKI', \\ Sakae UTSUNO" ${ }^{\prime \prime}$ and Jun IGARI' \\ Department of Obstetrics and Gynecology, Juntendo University, Juntendo Urayasu Hospital \\ "Department of Clinical Pathology, Juntendo University, School of Medicine \\ Department of Obstetrics and Gynecology, Urayasu Ichikawa City Hospital \\ (Received: October 8, 1998) \\ (Accepted : January 25, 1999)
}

Key words : sexually transmitted diseases, human papillomavirus (HPV), hybrid

capture HPV DNA assay, cervical intraepithelial neoplasia

\begin{abstract}
The purpose of this study was to determine the prevalence of infection due to human papillomavirus (HPV) types of high and intermediate oncogenic risk, which was most frequently associated with uterine cervical neoplasia. The subjects were 236 prostitutes who visited a sexually transmitted diseases (STD) clinic in a metropolitan area in 1998. Another 95 women who visited a university hospital were selected as a normal control group. A swab sample collected from the uterine cervix and external os was subjected to hybrid capture assays for low-oncogenic-risk HPV types (HPV A ; including types 6, 11, 42, 43 and 44) and high- and intermediate-oncogenic-risk HPV types (HPV B ; including 16, 18, 31, 33, 35, 39, $45,51,52,56,58,59$ and 68). Chlamydia trachomatis and Neisseria gonorrhoeae. Fisher's exact test was used for statistical analyses. Among the microorganisms tested, the positive rate for HPV B was the highest both in the women attending the STD clinic (STD group) and in the control group. The positive rate for HPV B in the STD group was 47.5\% (112 of 236), and this was significantly higher than the 5.3\% (5 of 95) in the control group $(\mathrm{p}<0.0001)$. These findings suggest that HPV examination is recommended for women who visit an STD clinic to assess the future risk of cervical neoplasia.
\end{abstract}

\section{Introduction}

High-and intermediate-oncogenic-risk type human papillomavirus (HPV) are most frequently associated with uterine cervical intraepithelial neoplasia (CIN) and invasive cervical cancer ${ }^{1.22}$. Using the hybrid capture assay, we e $^{3 \prime}$ previously detected HPV DNA of high- and intermediate-oncogenic-risk types in 13.9\% (23 of 169) of samples from women with Pap smear Class I or II, and 70.6\% (48 of 68) of samples with Pap smear Class III, IV or V $(\mathrm{p}<0.0001)$. We also detected HPV DNA in 29.0\% (18 of 62) of the women with no evidence of cervical intraepithelial neoplasia and $78.6 \%$ (44 of 56) in those with cervical in-

Correspondence to : Takeyoshi KUBOTA, M.D.

Department of Obstetrics and Gynecology, Juntendo University, Juntendo Urayasu Hospital, 2-1-1 Tomioka, Urayasu-city, 279-0021, Chiba. Japan

平成11年 3 月 2011 
traepithelial lesions or cervical cancer $(\mathrm{p}<0.0001)$. Since HPV infection occurs frequently in conjunction with chlamydial and gonococcal infections", examination of HPV DNA is recommended together with Chlamydia trachomatis and Neisseria gonorrhoeae in patients suspected of STD. For this reason we investigated the prevalence of HPV infection together with that of chlamydial infection and gonorrhea in patients who visited a Sexually transmitted disease (STD) clinic.

\section{Materials and Methods}

The subjects were 236 consecutive prostitutes who visited an STD clinic in a metropolitan area between June and September 1998 for an STD checkup. The cytological findings of the women were unknown. Their age ranged from 18 to 48 years with a mean age of $29.1 \pm 4.9$ years (mean \pm SD). A control group consisting of 95 consecutive women who visited the Department of Obstetrics and Gynecology, Juntendo Urayasu Hospital, Juntendo University, between October 1997 and March 1998 for an annual routine checkup, excluding those with Papanicolaou smear Classes IIIa, IIIb. IV and V, was selected. Their age ranged from 17 to 73 years with a mean age of $37.0 \pm 12.2$ years (mean $\pm \mathrm{SD}$ ).

Samples for hybrid capture assays were obtained by firmly wiping a swab with a Dacron stick across the cervix and external os. The swab was immediately placed into a specimen collection tube containing $1.0 \mathrm{ml}$ of preserving fluid and stored at $-80^{\circ} \mathrm{C}$ until it was assayed.

Hybrid capture assays for HPV, Chlamydia trachomatis and Neisseria gonorrhoeae were performed using Hybrid Capture Assay Kits (Digene Diagnostics, Maryland, USA). The hybrid capture kit for HPV contained two separate HPV probe mixtures. One probe mixture, designated A, detects low-oncogenicrisk HPV types, including types $6,11,42,43$ and 44 . The other probe mixture, designated B, detects highand intermediate-oncogenic-risk HPV types, including types 16, 18, 31, 33, 35, 39, 45, 51, 52, 56, 58. 59 and 68 . The kits for C. trachomatis and N. gonorrhoeae contained the respective probes for the two microorganisms. The assays were performed according to the directions of the manufacture as explained in previous reports ${ }^{3.5)}$. Briefly, the specimen was denatured and a ribonucleic acid (RNA) probe was added for hybridization. The DNA-RNA hybrids were captured onto the surface of a microplate coated with anti-DNARNA hybrid antibodies, and reacted with another anti-DNA-RNA hybrid antibody mixture conjugated with alkaline phosphatase. The RNA-DNA hybrids were detected by chemoluminescence. Samples were considered positive if the index value (test sample value/positive control value) was $\geqq 1.0$, and negative if the index value was $<1.0$.

Fisher's exact test was used for statistical analyses. A p value less than 0.05 was considered significant.

\section{Results}

In the STD, 98 women were negative for all 4 probes [low-risk HPV types (HPV A), high- and intermediate-risk HPV types (HPV B), C. trachomatis, and N. gonorrhoeae]. Seventy-four women were positive for HPV B alone, 14 for both HPV A and B, 12 for C. trachomatis and HPV B, 11 for HPV A alone. 10 for $C$. trachomatis alone, and 4 for HPV A, B and C. trachomatis. The other patterns of detection consisted of less than 4 women. In the control group, 86 women were negative for all 4 probes. Four women were positive for HPV B alone. The other patterns consisted of less than 4 subjects (Table 1).

The positive rate for HPV B in the STD group was 47.5\% (112 of 236), and this was significantly 
Table 1 Results of hybrid capture assays for HPV, C. trachomatis and N. gonorrhoeae in the uterine cervix in women attending an STD clinic

\begin{tabular}{|c|c|c|c|c|c|c|}
\hline & \multicolumn{4}{|c|}{ Hybrid Capture assays } & \multirow{2}{*}{$\begin{array}{c}\begin{array}{l}\text { Number of } \\
\text { commercial } \\
\text { sexual workers }\end{array} \\
\end{array}$} & \multirow{2}{*}{$\begin{array}{l}\text { Number of } \\
\text { normal controls }\end{array}$} \\
\hline & HPV A & HPV B & C. trachomatis & N. gonorrhoeae & & \\
\hline $\begin{array}{l}\text { All tests } \\
\text { negative }\end{array}$ & - & - & - & - & 98 & 86 \\
\hline \multirow{4}{*}{$\begin{array}{l}1 \text { test } \\
\text { positive }\end{array}$} & + & - & - & - & 11 & 0 \\
\hline & - & + & - & - & 74 & 4 \\
\hline & - & - & + & - & 10 & 3 \\
\hline & - & - & - & + & 2 & 0 \\
\hline \multirow{6}{*}{$\begin{array}{l}2 \text { tests } \\
\text { positive }\end{array}$} & + & + & - & - & 14 & 1 \\
\hline & + & - & + & - & 1 & 1 \\
\hline & + & - & - & + & 0 & 0 \\
\hline & - & + & + & - & 12 & 0 \\
\hline & - & + & - & + & 3 & 0 \\
\hline & - & - & + & + & 2 & 0 \\
\hline \multirow{4}{*}{$\begin{array}{l}3 \text { tests } \\
\text { positive }\end{array}$} & + & + & + & - & 4 & 0 \\
\hline & + & + & - & + & 2 & 0 \\
\hline & + & - & + & + & 0 & 0 \\
\hline & - & + & + & + & 2 & 0 \\
\hline $\begin{array}{l}\text { 4tests } \\
\text { positive }\end{array}$ & + & + & + & + & 1 & 0 \\
\hline Total & & & & & 236 & 95 \\
\hline
\end{tabular}

HPV A : low-oncogenic-risk HPV types

HPV B : high-and intermediate-oncogenic-risk HPV types

Table 2 Comparison of positive rates for HPV, C. trachomatis and $N$. gonorrhoeae between women attending an STD clinic and control women - positive results of hybrid capture assays performed on cervical samples.

\begin{tabular}{l|c|c|c|c}
\hline \multirow{2}{*}{} & \multicolumn{4}{|c}{ Positive rate \% (number of positive women/total number of women) } \\
\cline { 2 - 5 } & HPV A & HPV B & C. trachomatis & N. gonorrhoeae \\
\hline $\begin{array}{l}\text { Women } \\
\text { attending }\end{array}$ & $14.0(33 / 236)$ & $47.5(112 / 236)$ & $13.6(32 / 236)$ & $5.1(12 / 236)$ \\
$\begin{array}{l}\text { STD clinic } \\
\text { Control }\end{array}$ & & & & \\
group & $2.1(2 / 95)$ & $5.3(5 / 95)$ & $4.2(4 / 95)$ & $0(0 / 95)$ \\
P value & 0.0007 & $<0.0001$ & 0.0114 & 0.0220 \\
\hline
\end{tabular}

HPV A : low-oncogenic-risk HPV types

HPV B : high-and intermediate-oncogenic-risk HPV types

higher than the $5.3 \%$ ( 5 of 95$)$ in the control group $(\mathrm{p}<0.0001)$ (Table 2$)$. The positive rates for the other 3 probes were also significantly higher in the STD group than in the control group.

Among the microorganisms tested, the positive rate for HPV B was the highest in both the STD and in control groups (Table 2). There were no differences in the positive rate for HPV B among different age 
Table 3 Relationship between age and positive rate of HPV B (high-and intermediate-oncogenic-risk HPV types) in women attending an STD clinic

\begin{tabular}{c|c|c}
\hline \multirow{2}{*}{$\begin{array}{c}\text { Age group } \\
\text { (years) }\end{array}$} & \multicolumn{2}{|c}{ HPV B positive rate \% (cases) } \\
\cline { 2 - 3 } & Prostitutes & Normal control \\
\hline $18-19$ & $0 \%(0 / 1)$ & $25.0 \%(1 / 4)$ \\
$20-29$ & $51.2 \%(70 / 136)^{1)}$ & $12.9 \%(4 / 31)$ \\
$30-39$ & $43.5 \%(43 / 95)^{2)}$ & $0 \%(0 / 19)$ \\
$40-49$ & $0 \%(0 / 4)$ & $0 \%(0 / 24)$ \\
$50-59$ & & $0 \%(0 / 13)$ \\
$60-69$ & & $0 \%(0 / 3)$ \\
$70-79$ & & $0 \%(0 / 1)$ \\
\hline
\end{tabular}

1-2) $\mathrm{P}=0.4224$
Table 4 Relationship between length of tine as a prostitute and positive rate for HPV B (high-and intermediate-oncogenic-risk HPV types) in the uterine cervix in women attending an STD clinic

\begin{tabular}{l|c|c}
\hline & \multicolumn{2}{|c}{ HPV B positivity } \\
\hline $\begin{array}{l}\text { Length of time } \\
\text { enployed as a } \\
\text { prostitute }\end{array}$ & $\begin{array}{l}\text { Number of positive } \\
\text { women total number } \\
\text { of women }\end{array}$ & Positive rate ${ }^{\circ}$ \\
\hline $\begin{array}{l}\text { Within 1 year } \\
\text { More than 1 year }\end{array}$ & 1955 & $34.5^{\prime \prime}$ \\
\hline $1-2): p=0.0316$ &
\end{tabular}

groups in the STD group (Table 3). However, a significant difference in the positive rate for HPV B which depended on the length of time the woman had been a prostitute was observed (Table 4).

\section{Discussion}

A high detection rate of HPV in women attending STD clinics has been noted. Horn et al $(1991)^{6}$ reported that $52 \%$ of 116 such women in Maryland, USA were judged to be infected with HPV by at least one of the three criteria : the presence of genital warts, cytopathlogic evidence of HPV in Papanicolaou smear, and the presence of HPV DNA in Southern hybridization analysis of cervical scrapings. However. when Southern hybridization alone was used, the prevalence was $12 \%$ for HPV DNA in cervical scrapes. Borg $(1993)^{7)}$ analyzed 377 women who visited an Australian STD clinic and detected HPV DNA (types $6,11,16,18,31,33$ and 35$)$ in $12 \%$ of ectocervical samples using Dot blot hybridization. Figueroa et al $(1995)^{81}$ studied the prevalence of HPV among 202 STD clinic patients in Jamaica by performing Southern blot hybridization on cervical and vaginal cell samples, and identified 58 (28.7\%) women as HPV positive.

In the present study, we were able to compare the HPV detection rate between a group of women attending an STD clinic (STD group) and a normal control group, which was not explicitly reported in the past studies. The HPV B detection rate in the STD group was 47.5\% (112 of 236), and this was significantly higher than the rate of $5.3 \%$ (5 of 95) in the control group $(\mathrm{p}<0.0001)$. When low-risk HPV type and/or high- and intermediate-risk HPV type STD clinic patients were calculated, the proportion was 52.5 $\%(124 / 236)$, which is in agreement with Horns' prevalence rate of $52 \%$. The purpose of this study was to compare the prevalence of HPV B infection between a group of women attending an STD clinic (prostitutes) and a normal control group. For the normal control, we selected 95 consecutive women who visited the University Hospital for an annual routine checkup, excluding those with Papanicolaou smear Classes IIIa, IIIb, IV and V. If those with Papanicolaou smear Classes IIIa, IIIb, IV and V were included. there were 100 consecutive women (including 4 patients with Class IIIa who were negative for HPV A. HPV B, C. trachomatis and N. gonorrhoeae, and 1 patient with Class V who was positive for HPV B and negative for HPVA, $C$. trachomatis and $N$. gonorrhoeae). The positive rate for HPV B in the prostitutes was $47.5 \%$ (112 of 236) , and this was also significantly higher than the 6.0\% (6 of 100) in the 100 of consecutive women who visited the University Hospital $(\mathrm{p}<0.0001)$. 
HPV infection occurs frequently in conjunction with chlamydial and gonococcal infections ${ }^{4}$. In the presert study, the presence of these three microorganisms in a subject could easily be investigated from one cervical swab sample using hybrid capture assays. Using these assays, the positive rates for HPV A, HPV B, C. trachomatis and N. gonorrhoeae were significantly higher in the STD group than in the control group. Among the four microorganisms, the positive rate for HPV B was higher than those of the other three. This was more prominent in the STD group than in the control group. Ichinose ${ }^{9)}$ reported that the positive rates for $C$. trachomatis and $N$. gonorrhoeae in Japanese patients who visited ordinal gynecologic clinics in Tokyo with any symptoms suspected of STD were $10.4 \% \quad(1987-1997, \mathrm{n}=50,535$, by either enzyme immunoassay or DNA probe method) and 3.7\% (1992-1997, $\mathrm{n}=5,872$, by DNA probe method), respectively. Compared to these results, in our study the positive rates in the control group $(4.2 \%$ for C. trachomatis and $0 \%$ for $N$. gonorrhoeae) were lower and the positive rates in the STD group (13.6\% for C. trachomatis and $5.1 \%$ for $N$. gonorrhoeae) were higher. Therefore, our results are reasonable.

Previous studies have reported an age-dependent difference in HPV prevalence. According to the results of a Finnish nationwide cervical cancer screening study conducted between 1981 and 1989 (reported $1991)^{10}$, the highest prevalence $(6.1 \%)$ of genital HPV infection detected by cervicovaginal Papanicolaou smears was observed in women aged between 20 and 29 years, followed by $2.2 \%$ in those aged $30-39$ years. Figueroa et al $(1995)^{81}$ reported an HPV prevalence of $39 \%$ in women $15-19$ years old, 33\% in women $20-24$ years old, $31 \%$ in women 25-29 years old, and $17 \%$ in those 30 years or older. In the control group in this study, the positive rate of HPV B in women aged under 30 years $(n=35)$ was $14.3 \%$, and no women over $30(n=60)$ years were positive. Figueroa et al stated that the decrease in HPV prevalence in older women, which agrees with other studies, may be due to a biological effect, such as increased immunity to HPV with age. While a decrease in HPV prevalence in older women has been noted in other studies, our data showed no difference in the positive rate of HPV B among different age groups in the STD group [51.2\% (70/136) in 20 to 29 year-olds, $44.8 \% \quad(43 / 96)$ in 30 to 39 year-olds ; $p=0.4224$ ]. These findings suggest that the prostitutes in our sample remain at high risk of acquiring HPV, even as they get older. Furthermore, our finding that women who have worked for a long period of time as a postitute are associated with a significantly higher prevalence of HPV B [within 1 year, 34.5\% (19/55) ; more than 1 year ; 51.4\% (93/181) : $\mathrm{p}=0.0316]$ may support this hypothesis.

The present findings suggest that HPV examination is recommended for women who visit STD clinics to assess the future risk of CIN and cervical cancer.

\section{References}

1) Trofatter KF Jr : Diagnosis of human papillomavirus genital tract infection. Am J Med 1997 ; $102: 21-27$.

2) Sun XW, Fererczy A, Johnson D et al . : Evaluation of the Hybrid Capture human papillomavirus deoxyribonucleic acid detection test. Am J Obstet Gynecol $1995 ; 173: 1432-1437$.

3) Kubota T. Ishi K. Suzuki M et al . : Usefulness of hybrid capture HPV DNA assay as a diagnostic tool for human papillomavirus infection. J J A Inf D $1998 ; 72: 1219-1224$.

4) Furugen Y. Utsuno S, Suzuki M, Kubota T. Takada M : Superinfections and problems in treatment of STD high risk group. LASTD $1991 ; 14: 190-195$.

5) Ishi et al. : Usefulness of hybrid-capture HPV DNA detection kit for the diagnosis of HPV infection. Jpn J Med Pharm Sci $1998 ; 38: 849-853$.

6) Horn JE, McQuillan GM, Shan KV et al. : Genital human papillomavirus infections in patients attending an inner-city STD clinic. Sex Transm Dis $1991 ; 18: 183-187$.

平成11年 3 月 $20 \mathrm{H}$ 
7) Borg AJ, Medley G, Garland SM : Prevalence of HPV in a Melbourne female STD population : comparison of RNA and DNA probes in detecting HPV by dot blot hybridization. Int J STD AIDS $1993 ; 4: 159-164$.

8) Figueroa JP, Ward E, Luthi TE et al. : Prevalence of human papillomavirus among STD clinic attenders in Jamaica : association of younger age and increased sexual activity. Sex Transm Dis $1995 ; 22: 114-118$.

9) Ichinose M, Kobayashi Y, Matsuda S, Ando S, Oh K : Prevalence of Chlamydia trachomatisand Neisseria gonorroeae in gynecologic patients in Tokyo (1987-1997). (in Japanese) JASTD $1998 ; 9: 42$.

10) Syrjänen K, Yliskoski M, Kataja V et al. : Prevalence of genital human papillomavirus infections in a mass-screened Finnish female population aged 20-65 years. Int J STD AIDS $1990 ; 1: 410-415$.

\section{STD クリニック受診例における Human papillomavirus 感染の蔓延状況}

${ }^{11}$ 順天堂大学医学部附属順天堂浦安病院産婦人科, 21順天堂大学医学部臨床病理,

3)浦安市川市民病院産婦人科

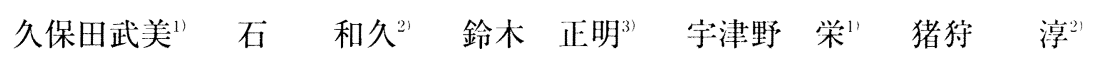

要旨

この研究の目的は子宮頸部の neoplasia と最も 関連深い高度・中等度 risk types の HPVによる 感染の蔓延状況を知ることである．対象はSTD clinic 受診例 236 例と control 群 (通常の婦人科外 来受診者）95例である. 両群ともに，子宮頸部擦 過物を採取し, DNA 診断法である hybrid capture 法を利用して, HPV の 6, 11, 42, 43, 44 型（HPV A), $16,18,31,33,35,39,45,51,52,56,58,59,68$ 型 (HPV B) およびC. trachomatis, N. gonorrhoeae
の検出を試みた. 分析には Fisherの直接法を用い た. HPV B の陽性率はSTD clinic 受診群, コント ロール群いずれの群においても最も高率であっ た. STD clinic 受診群と control 群での HPV B の検出率はそれぞれ $47.5 \%, 5.3 \%$ であり有意差 を認めた $(\mathrm{p}<0.00001)$. STD clinic 受診者におい ては，子宮頸部悪性病変のリスクを知るために HPV の検査を施行する意義のあることが示唆さ れた。 